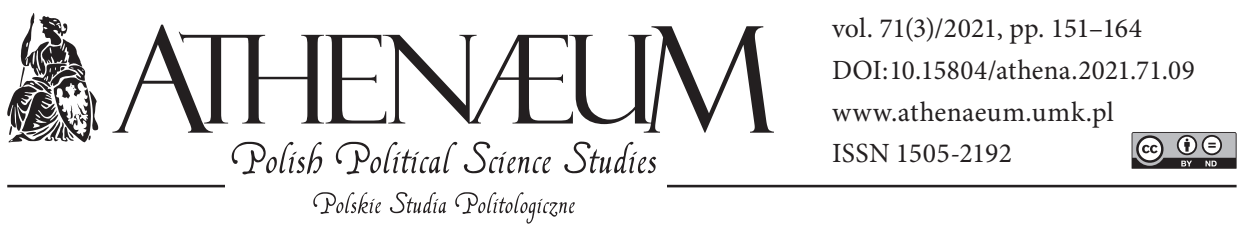

\title{
POST-SOVIET AREA IN THE FOREIGN POLICY OF THE RUSSIAN FEDERATION
}

\author{
OBSZAR PORADZIECKI W POLITYCE ZAGRANICZNEJ \\ FEDERACII ROSYJSKIEJ
}

Anna Czyż*

\begin{abstract}
Artykuł jest poświęcony miejscu obszaru poradzieckiego $\mathrm{w}$ rosyjskiej polityce zagranicznej od rozpadu Związku Radzieckiego w 1991 do 2021 roku. Celem artykułu jest przedstawienie znaczenia obszaru poradzieckiego $\mathrm{w}$ rosyjskiej polityce zagranicznej oraz celów i instrumentów tej polityki wobec obszaru poradzieckiego po rozpadzie ZSRR. W ciągu 30 lat po rozpadzie Związku Radzieckiego na obszarze poradzieckim miały miejsce procesy reintegracji i dezintegracji. Dochodziło do wielu konfliktów zbrojnych, stał się on także polem rywalizacji w stosunkach międzynarodowych. Federacja Rosyjska wykorzystuje wszelkie możliwe instrumenty oddziaływania, aby utrzymać kontrolę nad obszarem poradzieckim i nadal traktuje go jako wyłączną strefę wpływów Rosji i priorytetowy kierunek rosyjskiej polityki zagranicznej.
\end{abstract}

Słowa kluczowe: obszar poradziecki; Federacja Rosyjska; polityka zagraniczna; reintegracja; Władimir Putin
The article is devoted to the post-Soviet area's place in Russian foreign policy from the collapse of the Soviet Union in 1991 to 2021. The aim of this article is to present the importance of the post-Soviet area in Russian foreign policy and the goals and instruments of this policy towards the post-Soviet area after the collapse of the USSR. In the 30 years after the collapse of the Soviet Union, reintegration and disintegration processes took place in the post-Soviet area. There were numerous armed conflicts, and it also became a field of competition in international relations. The Russian Federation uses all possible influence instruments to maintain control over the post-Soviet area and still treats it as the exclusive sphere of Russian influence and Russian foreign policy's priority direction.

Keywords: post-Soviet area; the Russian Federation; foreign policy; reintegration; Vladimir Putin

* Univeristy of Silesia in Katowice, Faculty of Social Sciences. 
The term 'post-Soviet area' refers to the countries located to the south and west of the Russian Federation. They were created after the collapse of the Soviet Union in the region of Eastern Europe (Belarus, Moldova, Ukraine), the South Caucasus (Armenia, Azerbaijan, Georgia), and Central Asia (Kazakhstan, Kyrgyzstan, Tajikistan, Turkmenistan, Uzbekistan). The exception is made for the Baltic republics because they chose to join the EU and NATO in 2004. Until 2009, the post-Soviet area's equivalent was the Commonwealth of Independent States (CIS). Still, when Georgia left the CIS, it left the region somewhat 'without a name. The collapse of the Soviet Union in December 1991 meant the need to redefine international relations in the Eurasian region. As the main political and legal successor of the Soviet Union, the Russian Federation faces the formulation of its foreign policy towards the post-Soviet area. The importance of the post-Soviet area in Russia's policy is determined by several factors: territorial proximity, challenges, and threats coming from there (Islamic fundamentalism, terrorism, organized crime, drug trafficking, illegal migration), strategic location (communication and trade routes, e.g., the Silk Road), economic ties, centuriesold historical, cultural and religious ties, a significant number of Russian and Russian-speaking people living in post-Soviet republics.

Thirty years have passed since the collapse of the Soviet Union. At that time, many studies covered many aspects of the post-Soviet area's functioning, and the Russian Federation's policy towards the so-called 'near abroad' appeared. Among Polish authors dealing with the discussed topic, there are works by: A. Włodkowska-Bagan, T. Stępniewski, M. Raś. Foreign authors dealing with the issues related to the post-Soviet area include, among others, G. Toal, A. Skriba, A.A. Kazantsev. The article is based on an analysis of Polish and English literature on the subject mentioned above. The research method used in this work is the method of analyzing the sources in the form of the concepts of the foreign policy of the Russian Federation adopted during the presidency of subsequent presidents. The article uses a systemic method treating the post-Soviet area as a system influenced by the policy of the Russian Federation and a decisionmaking method to determine specific instruments of influence of the Russian Federation concerning the post-Soviet area. The article is based on a subject, problematic approach, as it refers to several challenging issues that seem to be of crucial importance regarding the significance of the post-Soviet area in Russian foreign policy. 
The main research question is: What are the post-Soviet area's position and place in Russian foreign policy after the USSR collapsed in 1991? Detailed research questions refer to the most critical problems in the post-Soviet area's functioning. They are as follows: What were and are the Russian foreign policy's objectives and instruments concerning the post-Soviet area? What processes are taking place in the post-Soviet area? What conflicts took place in the post-Soviet area, and how did they affect the post-Soviet countries' security? What interests do other entities of international relations have in the post-Soviet area?

The article's central thesis is: the Russian Federation uses all possible influence instruments to maintain control over the post-Soviet area, treated as the exclusive sphere of Russian influence and the priority direction of Russian foreign policy.

Detailed theses refer to the research questions posed:

- the main goals of Russian foreign policy towards the post-Soviet area include the political, economic, and military integration of this area under the leadership of Russia,

- the essential instruments of Russian influence in the post-Soviet area include political, military, economic, and the so-called soft power - Russia has a 'comprehensive' impact on the countries of the post-Soviet region,

- in the post-Soviet area, there are mainly reintegration processes inspired by Russia, but also disintegration processes take place through the creation of alternative cooperation structures, bypassing Russia,

- the post-Soviet area is an arena of several unresolved conflicts (the socalled 'frozen conflicts'), which Russia uses as instruments of pressure on rebellious countries that choose the pro-Western option in their foreign policy,

- the post-Soviet area is a field of rivalry between Russia, China, and the West since each of these actors has their interests in this area; Russia is committed to eliminating the influence of third countries in the postSoviet area.

\section{OBJECTIVES AND INSTRUMENTS OF THE FOREIGN POLICY OF THE RUSSIAN FEDERATION TOWARDS THE POST-SOVIET AREA}

For 30 years, the post-Soviet area has been a priority direction in the Russian Federation's foreign policy (Nikitin, 2008, p. 7). Its priority importance for Russia has been emphasized in all foreign policy programming documents, starting 
from 1993, when The Russian Federation's Concept of the Foreign Policy was published (April 23, 1993). This document should be considered the first to define Russia's priorities for international activity. The following four concepts of the Russian foreign policy (of June 28, 2000, July 12, 2008, February 18, 2013, and November 30,2016) differ in assessing challenges, threats, goals, means, and methods. It is understandable because of the evolution of international relations and Russia's global environment, but the 'near abroad' takes a key place in them. Since the Russian Federation's establishment, the Russian decision-makers initially used the term 'near abroad' to describe the fourteen former Soviet republics. As a result of opposition from the three Baltic republics, which explicitly opted for a pro-Western direction in foreign policy, the term 'near abroad' is currently used in official state documents for only eleven former Soviet republics. The term 'near abroad' means that Russia perceives the 'near abroad' countries through the prism of specific historical, political, and economic ties, strategic importance, character, and uniqueness, in which vital Russian interests focus.

One of the fundamental and unchanging Russian foreign policy goals has become strategic control over the post-Soviet area. It has been recognized as 'Russia's sphere of interests' because, for Russia, one of the main conditions for maintaining superpower status is its domination in the post-Soviet area (Mankoff, 2011, p. 345). Russia's strategic goal is to create a regional order in the post-Soviet area dominated by Russia, including building integration structures subordinate to Moscow. The primary and most crucial goal of Russia concerning the post-Soviet area is to keep it within the sphere of Russian influence, i.e., to limit the impact of other actors potentially having a strong voice in essential matters for the region and to take care that any of the geopolitical players does not contest this prerogative (Zhiltsov, 2018, p. 10).

Russia's goals concerning the post-Soviet area focus on four main areas: politics, security, economy, and the so-called soft power (Ebzeeva, 2017, p. 20). In Russia's political sphere, the post-Soviet area countries must not form alliances with other external actors but remain in the structures of cooperation controlled by Russia. In the sphere of security, Russia's primary goal is to cover the entire post-Soviet area with the collective security system guaranteed by Russia. In the sphere of economy, Russia aims to maintain the countries' dependence on trade with each other in selected sectors and supporting the transit monopoly position of energy resources (Skriba, 2016, p. 610). In soft power, Russia depends on retaining the Russian language and Russian media position in the region. The tool used in this sphere of Russian influence has been the concept of the 'Russian 
world', which is a form of promoting the idea of Russia as a civilization center separate from Asian civilizations and opposed in many ways to Western culture (Freire, 2019, p. 800).

Russia has a wide range of instruments to influence the countries of the post-Soviet area. They can be grouped into four main overlapping categories: 1) political, 2) military, 3) economic, 4) soft power (Rutland \& Kazantsev, 2016, p. 396). One of the political instruments is domination in regional cooperation structures established at Russia's initiative in the post-Soviet area. Reintegration is one way of maintaining and strengthening Russian influence in the post-Soviet area and limiting third actors' impact in the region. In the political and security dimension, the key organizations from Russia's perspective are the Commonwealth of Independent States (CIS), the Collective Security Treaty Organization (CSTO), and the Shanghai Cooperation Organization (SCO). The strengthening of Russia's position in the post-Soviet countries is also promoted by disseminating its political model - 'sovereign democracy' (Okara, 2007, p. 9) and supporting leaders favorable to Russia and its reintegration projects. 'Sovereign democracy' is a remedy for 'color revolutions' and the expansion of other actors' influence in the post-Soviet area.

The most spectacular instrument is the Russian military presence in many former republics and Moscow's involvement in armed conflicts in the post-Soviet area, which in most cases remain unresolved to this day (Strachota, 2003, p. 80). Military bases are a form of guaranteeing the Russian military presence in the former Soviet republics. Under the agreements concluded in the 1990s, Russia obtained military bases in Armenia, Georgia, Tajikistan, Moldova, Kyrgyzstan, and Ukraine (Black Sea Fleet). Moreover, according to bilateral agreements, Russia had at its disposal radar stations in Azerbaijan, Kazakhstan, Belarus, communication nodes, and the Baikonur cosmodrome in Kazakhstan. Having military bases in 'near abroad' countries, apart from security and stabilization in regional conflict, is also justified by protecting the Russian and Russian-speaking minorities living in conflict regions. Russia was a mediator in all the conflicts that took place in the post-Soviet area. It was the leading creator of the agreements and their guarantor, and often the support for separatism and the participation of Russian forces on one of the sides of the conflict determined its outcome (Gvosdev \& Marsh, 2013, p. 456). The economic instruments include: Russian assets in various countries in the region, a dominant position in the transit of energy resources through the Russian territory to recipients in the West, Russia's tariff policy on goods exported to the countries of the region, the application 
of a policy prohibiting importing certain goods from countries defiant against Russia through economic embargoes. Concerning some countries (Belarus, Ukraine), Russia applied a preferential prices policy to supply energy resources. In the event of deteriorating relations, it resorted to pressure and economic blackmail. They led to gas crises and pursuing a policy of 'bypassing' the existing transit countries, i.e., Belarus and Ukraine, by pushing for new infrastructure investments (construction of the Nord Stream I and II gas pipeline, or Turkish Stream). A characteristic principle in Russia's policy is that a state that cooperates or shows a willingness to cooperate is rewarded, and those that oppose Russia are punished. Russia uses 'hard' tools in its policy towards the 'rebellious' in such a situation. They are trade blockade, energy embargoes, differentiating energy prices depending on the level of compliance of a given state's policy with Russian interests, taking over infrastructure, especially energy, supporting separatisms, and military action or economic blackmail.

The concept of soft power means to achieve goals and is an extension of the possible ways of influencing and achieving goals by actors in international relations. Therefore, it attempts to show the 'other face of strength', that is, opposition to the hard power components of power - military and economic. According to Joseph Nye's definition, soft power is the state's ability to get what it wants through attractiveness, not through coercion or payment (Nye, 2004, p. 191). The soft power category includes cultural closeness, knowledge of the Russian language, interpersonal contacts, access to Russian media (television, the Internet, press), contacts with the Orthodox churches, the rhetoric of brotherhood (the concept of the Russian world). Mark Leonard and Nicu Popescu propose the following catalog of 'soft' tools of the Russian neighborhood policy: Russian mass media, financing of NGOs, economic growth, visa-free movement, open labor market, authoritarian capitalism, supporting authoritarian regimes, exporting 'sovereign democracy', Russian citizenship and pensions, military training (Leonard \& Popescu, 2008, p. 89).

\section{REINTEGRATION AND DISINTEGRATION PROCESSES IN THE POST-SOVIET AREA}

From the moment the decision to break up the Soviet Union was taken, it became clear that Russia would try to rebuild its influence in the post-Soviet area and use the existing ties to continue cooperation with the new, already independ- 
ent republics. Its main task was to maintain unique relations with the former republics. In the first half of the 1990s, Russia attempted to recreate integration ties encompassing all or the vast majority of the former Soviet republics. When this strategy did not bring the expected results, Russia chose a so-called multispeed integration to deepen integration in groups of states and specific spheres (political, economic, security) (Krickovic, 2014, p. 519). These tendencies then intensified in the 2000s, after Vladimir Putin came to power, when other Russian projects for deeper integration appeared (Rumer, 2019, p. 62). It concerns the political, economic, and security spheres. As part of political cooperation, the post-Soviet area's main structure is the Commonwealth of Independent States (Kembayev, 2009, p. 217). Despite ambitious and far-reaching plans supported by nearly a thousand agreements, the CIS did not meet Russian expectations. The failure of integration within the CIS is associated with the growing involvement of third countries in the region and the strengthening of the western direction in some former Soviet republics' politics. The most important reintegration project in economic cooperation is currently the Eurasian Economic Union (Papava, 2019, p. 18).

On the other hand, in the field of security, the former Soviet republics cooperate based on the Collective Security Treaty Organization. Cooperation within these structures remains largely declarative and ineffective, and the primary goal of these organizations is to maintain Moscow's political influence in individual regions. The post-Soviet institutional cooperation's practice proves that former USSR republics are incapable of creating effective integration structures, both in the twelve formats and in a smaller group. For Moscow, integration projects are essential in two dimensions - economic and geopolitical. In the first dimension, they are to be a response primarily to China's economic expansion. In the second one - to prove Russia's superpower position and give it an asset in relations with other global players.

In the post-Soviet area, one can observe the reintegration processes inspired by Russia, on the one hand. On the other hand, there are disintegration trends pushed by some countries created after the collapse of the Soviet Union, which tried to resist Russia's domination and did not enter into joint structures of cooperation with it. The most advanced manifestation of disintegration in foreign and security policy was the example of the Baltic republics, which ruled out the possibility of participating in any institutionalized forms of cooperation proposed by Russia. The determined position of Lithuania, Latvia, and Estonia on the choice of the pro-Western option and the consistent striving for membership 
in the European Union and NATO led to the extension of these structures by three Baltic republics in 2004. A manifestation of a more decisive turn to the West by some former Soviet republics was the emergence of alternative groups without Russia and the 'color revolutions' which brought decidedly pro-Western politicians to power. In some of the former Soviet republics, the GUAM project (bringing together four countries: Georgia, Ukraine, Azerbaijan, and Moldova) was founded in 1997, transformed in 2006 into a regional organization called GUAM - Organization for Democracy and Economic Development. Its members declared, among other things, a continuation of activities aimed at European integration by strengthening ties with the European Union and NATO. There have been so-called 'color revolutions' in some countries as peaceful protests and social movements resulting from social and political changes. In Georgia, the 'Rose Revolution', in Ukraine the 'Orange Revolution', and in Kyrgyzstan, the 'Tulip Revolution' have resulted in numerous forecasts of the spread of democratic changes in the post-Soviet area. The events of the color revolutions confirmed the aspirations for pro-Western integration. They contradicted the policy of reintegration of the post-Soviet area pushed by Russia. Some of the former post-Soviet republics did not agree to Russia's subordination system in the structures of cooperation, characterized by asymmetry in favor of Russia. For the latter group of countries 'defiant' towards Russia, cooperation with the European Union under the European Neighborhood Policy and the Eastern Partnership program was of great importance (Korosteleva, 2011a, p. 252).

\section{MILITARY CONFLICTS IN THE POST-SOVIET AREA}

The post-Soviet area is the scene of many unresolved conflicts. Their genesis dates back to the times of the Soviet Union, and the direct cause of their outbreak in the early 1990s was the desire to take advantage of the situation when the fate of the USSR was at stake. Thus, the collapse of the Soviet Union was accompanied by local ethnic and ideological armed conflicts that arose from deep historical conditions and the USSR's national policy and the gradual political, economic and social disintegration that engulfed the USSR. The most important armed conflicts in the post-Soviet area concern: Abkhazia and South Ossetia (Georgia), Transnistria (Moldova), Nagorno-Karabakh (Azerbaijan), and recently eastern Ukraine joined this group. In the literature on the subject, they are sometimes called 'frozen conflicts' (Kazantsev et al., 2020, p. 148). Their phenomenon is that 
most of them did not conclude with a peace agreement. It was not possible to find a satisfactory solution for all interested parties. They continue to destabilize the situation in the post-Soviet area. Each of these conflicts has its specificity. Still, despite many differences (e.g., intensity, number of victims, parties involved, degree of internationalization), most of them also show standard features, e.g., in terms of genesis, course, and evolution, place in regional policy, geopolitical conditions, or short and long-term consequences for conflict-affected areas and their surroundings. The most important standard features include the following:

1) Most of them went through similar phases - from the so-called hot (military) phase, when armed struggles continued, through the normalization phase aimed at a peaceful resolution of the conflict. In some cases, the 'defrosting of the conflict' took place when the opposing parties again attempted to solve the problem by armed struggle (the subject of Nagorno-Karabakh in 2016 and 2020 or the war in Georgia in 2008). However, a permanent settlement of conflicts was not achieved either by force or by negotiation, often in a multilateral format, with external actors' involvement (UN, CSCE/OSCE, European Union).

2) In most conflict-affected areas, para-states (quasi-states) were established, which became a permanent element of the balance of power in the region, strengthened their independence, and got out of the appropriate control states. The situation of para-states means that separatist regions have the attributes of power but lack of international recognition. With each subsequent year of existence, para-states deepen the division with their home states on the political and economic levels and ordinary citizens' practices.

3) Russian support for para-states takes the form of military aid (rearmament), political support (partiality in mediation), and economic support (economic aid for rebellious republics).

4) The persistence of the situation of freezing conflicts negatively affects the situation in the region - on the one hand, conflicts hinder the development of the appropriate states, on the other, para-states become a base for terrorism, smuggling, organized crime, and other negative phenomena. When excluded from external forces' control, they create conditions for developing illegal activities, making the sensation of the so-called 'black holes'.

5) Conflicts have become a permanent element of the political game in international relations, becoming in the hands of Russia an essential 
instrument of torpedoing all efforts of the mother states to integrate with the European Union or NATO (Malyarenko \& Wolff, 2018, p. 201). In most cases, these countries became the object of geopolitics, not their subject, and their relations with the world were in line with the general tendencies of relations between the more important and more decisive international players: Russia, the USA, Turkey, Iran, China, OSCE, EU, and NATO (Allison, 2017, p. 524).

6) Russian forces have played and continue to play an essential role in developing the situation stationed in most para-states. The prolongation of the existing conflicts and the promotion of separatism is part of the divide and rule policy (Rezvani, 2020, p. 889). Russia can keep the conflict 'frozen', which enables it to use it as an instrument of pressure or to 'unfreeze' it at any convenient time.

\section{THE POST-SOVIET AREA AS A FIELD OF COMPETITION IN INTERNATIONAL RELATIONS}

After the collapse of the Soviet Union, the increasing involvement of third countries in the region became a severe challenge for Russia in the post-Soviet area. It turned out that the former Soviet republics, for various reasons, became an object of interest from other countries, such as the United States, European Union countries, China, Turkey, and Iran. Initially, these actors' activity in the post-Soviet area resulted, among other things, from the desire to fill the political vacuum that appeared there after the collapse of the USSR and the related danger of destabilization of the post-Soviet area. Natural resources were also crucial for all the actors involved, especially oil and gas, as the post-Soviet countries (to a varying degree) have significant energy resources and belong to global producers and exporters of oil and gas. The region of particular interest has become the Caspian region, where Russia's interests and the interests of the Caspian states (Azerbaijan, Kazakhstan, and Turkmenistan), the US, the European Union, and transnational companies clash. The post-Soviet area has become a field of rivalry, the formation of interest zones, the intersection of communication and trade routes, and the transport of energy resources (Sussex, 2012, p. 216). The reasons for the interest in the post-Soviet area by other entities are political, military, and economic. 
The growing interest and involvement of third countries in the post-Soviet area caused concern in Russia about the possibility of displacing it from its traditional sphere of influence, which would undermine its superpower status. Russia is the only one active in the post-Soviet area in the political, military, economic, social and cultural spheres. The other actors focus their policy towards this region on selected locations: China, primarily on the economy (energy supplies), the United States on security (the Central Asia region was important during Afghanistan's American mission). On the one hand, Russia's policy towards the former Soviet republics is to maintain Russian influence in the spheres of involvement mentioned above, and on the other hand, to restrain and limit the impact of other players interested in this region.

The factors that influenced the United States' increased interest in the postSoviet area, mainly in the South Caucasus and Central Asia, were connected with Afghanistan's anti-terrorist operation. The geographical proximity of the Caucasian and Central Asian states to Afghanistan contributed to the interest and intensification of the United States' activities in the possibility of deploying its military bases in this region. Based on bilateral agreements, the Americans opened their air bases in Kyrgyzstan (in Manas) and Uzbekistan. The European Union and the USA are involved in resolving conflicts in the CIS area. The stabilization of the situation in this still troubled region determines the constant and stable supplies of energy resources and the creation of conditions for constructing alternative pipelines to Russia and ensuring the diversification of energy supplies to bypass Russia. For years, the EU's goal was to implement the concept of building the so-called 'southern corridor', covering infrastructure connections of the EU and the Caspian countries via Turkey. An essential prerequisite for the activity of Western countries in the post-Soviet area is their democratization. Significant financial resources have been allocated to this goal since the beginning of the 1990s because, in the opinion of European and American decision-makers, all processes related to democratization constitute the basis of stability and security. To strengthen their position in the region, Western European countries and the USA are also to involve post-Soviet countries in cooperation with NATO and implement the Eastern Partnership program.

The basis of Chinese involvement in Central Asia is security issues. China seeks to secure the western Xinjiang province against possible destabilization spreading from or supported by Central Asian states in the local dimension. In a broader perspective, Beijing is interested in securing its interests towards Russia and the US, both present and active in the region. The post-Soviet area, and espe- 
cially Central Asia, is playing an increasingly important role in economic issues of strategic importance for China (especially energy, but also communication). China has emerged as a strategic financial partner for the region, most evident in the trade, energy, and infrastructure sectors (Strachota \& Jarosiewicz, 2013, p. 84).

\section{CONCLUSIONS}

According to President Putin, the Soviet Union's collapse was the greatest geopolitical catastrophe of the $20^{\text {th }}$ century. Thirty years after the collapse of the Soviet Union, the post-Soviet area remains the critical direction of Russian foreign policy as Russia's vital interests focus on this area. The so-called imperial syndrome', manifested in the need to be a superpower, concerns Russia. One of the main conditions for maintaining superpower status is its domination in the post-Soviet area. The Russian Federation uses all possible influence instruments to maintain control over the post-Soviet area, treated as the exclusive sphere of Russian influence. Among the tools of impact on former Soviet republics, one should include some of the most important: political, military, economic, and the so-called soft power. Russia has a 'comprehensive' impact on the countries of the post-Soviet area. Russia's goal concerning the post-Soviet area is also to contain and limit the influence of other players interested in the region.

Russia has a dominant position among all the former Soviet republics regarding political, military, and economic potential. Russia's policy towards the post-Soviet area affects the political strategies of the former Soviet republics. Among the former Soviet republics there can be distinguished:

1) the West-oriented outspoken opponents, openly resisting Russian ambitions and applying to Western organizations such as NATO or the EU (Georgia, Ukraine, Moldova - the leaders of the Eastern Partnership program),

2) pragmatic-oriented players with pendulum behavior (Uzbekistan, Azerbaijan) or countries calling itself 'neutral' (Turkmenistan),

3) relatively stable partners of Russia, representing the core of the CIS organization and participating in all Russia-led integration projects in the post-Soviet area (Kazakhstan, Belarus),

4) faithful followers of Russia whose security (sovereignty) depends on Big Brother (Armenia, Tajikistan, Kirgizstan). 


\section{REFERENCES:}

Allison, R. (2017). Russia and the Post-2014 International Legal Order: Revisionism and Realpolitik. International Affairs, 93(3), 519-543. DOI: 10.1093/ia/iix061.

Ebzeeva, Y. (2017). The Place of the Post-Soviet Space in the Foreign Policy Planning of Russia. Central Asia and the Caucasus, 18(2), 18-25.

Freire, M.R. (2019). The Quest for Status: How the Interplay of Power, Ideas, and Regime Security Shapes Russia's Policy in the Post-Soviet Space. International Politics, 56(6), 795-809. DOI: 10.1057/s41311-018-0164-y.

Gvosdev, N., \& Marsh, Ch. (2013). Russian Foreign Policy: Interests, Vectors, and Sectors. Los Angles: CQ Press.

Kazantsev, A.A., Rutland, P., Medvedeva, S.M., \& Safranchuk I.A. (2020). Russia’s Policy in the 'Frozen Conflicts' of the Post-Soviet Space: From Ethno-Politics to Geopolitics. Caucasus Survey, 8(2), 142-162. DOI: 10.1080/23761199.2020.1728499. Kembayev, Z. (2009). Legal Aspects of the Regional Integration Processes in the Post-Soviet Area. Berlin, Heidelberg: Springer.

Korosteleva, E. (2011a). Change or Continuity: Is the Eastern Partnership an Adequate Tool for the European Neighbourhood? International Relations, 25(2), 243-262. DOI: $10.1177 / 0047117811404446$.

Korosteleva, E. (2011b). The Eastern Partnership Initiative: A New Opportunity for the Neighbours? Journal of Communist Studies and Transition Politics, 27(1), 1-21.

Krickovic, A. (2014). Imperial Nostalgia or Prudent Geopolitics? Russia's Efforts to Reintegrate the Post-Soviet Space in Geopolitical Perspective. Post-Soviet Affairs, 30(6), 503-528. DOI: 10.1080/1060586X.2014.900975.

Legucka, A. (2013). „Rozmrażanie” konfliktów zbrojnych na obszarze poradzieckim. Rocznik Instytutu Europy Środkowo-Wschodniej, 11(4), 81-108.

Leonard, M., \& Popescu, N. (2008). Rachunek sił w stosunkach Unia Europejska-Rosja. Londyn-Warszawa: Europejska Rada Spraw Zagranicznych, Fundacja im. Stefana Batorego. Retrieved February 2, 2021 from: https://www.batory.org.pl/upload/files/ pdf/rachunek_sil_ue_rosja.pdf.

Lo, B. (2002). Russian Foreign Policy in the Post-Soviet Era. London: Palgrave Macmillan UK.

Malyarenko, T., \& Wolff, S. (2018). The Logic of Competitive Influence-Seeking: Russia, Ukraine, and the Conflict in Donbas. Post-Soviet Affairs, 34(4), 191-212.

Mankoff, J. (2011). Russian Foreign Policy: The Return of Great Power Politics. Plymouth: Rowman \& Littlefield.

Menkiszak, M. (2019). A Strategic Continuation, a Tactical Change: Russia's European Security Policy. Point of View, 76. Retrieved February 2, 2021 from: https://www.osw. waw.pl/sites/default/files/PW_76_A\%20strategic\%20continuation_net.pdf.

Nielsen, K.L., \& Vilson, M. (2014). The Eastern Partnership: Soft Power Strategy or Policy Failure? European Foreign Affairs Review, 19(2), 243-262.

Nikitin, A. (2008). Russian Foreign Policy in the Fragmented Post-Soviet Space. International Journal on World Peace, 25(2), 7-31. DOI: 10.2307/20752831. 
Nye Jr., J.S. (2004). Soft Power: The Means to Success in World Politics. New York: Public Affairs.

Okara, A. (2007). Sovereign Democracy: A New Russian Idea or a PR Project? Russia in Global Affairs, 5(3), 8-20.

Papava, V. (2019). The Central Caucaso-Asian Countries and the Prospects of Accession to the Eurasian Economic Union. Central Asia and the Caucasus, 20(2), 16-23.

Raś, M., \& Szkop, E. (2014). Stosunki Rosja-Unia Europejska po kryzysie krymskim. Rocznik Instytutu Europy Środkowo-Wschodniej, 12(5), 43-57.

Rezvani, B. (2020). Russian Foreign Policy and Geopolitics in the Post-Soviet Space and the Middle East: Tajikistan, Georgia, Ukraine and Syria. Middle Eastern Studies, 56(6), 878-899. DOI: 10.1080/00263206.2020.1775590.

Rumer, E.B. (2007). Russian Foreign Policy Beyond Putin. Abingdon-New York: Routledge.

Rutland, P., \& Kazantsev, A. (2016). The Limits of Russia’s 'Soft Power'. Journal of Political Power, 9(3), 395-413. DOI: 10.1080/2158379X.2016.1232287.

Skriba, A. (2016). Russian Strategy towards the Post-Soviet Space in Europe: Searching for Balance between Economy, Security, and Great Power Attractiveness. Strategic Analysis, 40(6), 604-618. DOI: 10.1080/09700161.2016.1224061.

Stępniewski, T. (2014). Cele rosyjskiej inwazji i okupacji na Ukrainie oraz reakcja Zachodu i Europy Środkowej. Rocznik Instytutu Europy Środkowo-Wschodniej, 12(5), 13-24.

Strachota, K. (2003). Armed Conflicts in the Post-Soviet Region: Present Situation, Prospects for Settlement. Consequences. OSW Studies, 9. Retrieved February 2, 2021 from: https://www.osw.waw.pl/sites/default/files/prace_9_1.pdf.

Strachota, K., \& Jarosiewicz, A. (2013). China vs. Central Asia: The Achievements of the Past Two Decades. OSW Studies, 45. Retrieved February 3, 2021 from: https://www. osw.waw.pl/sites/default/files/prace_45_cina_vs_asia_ang-net.pdf.

Sussex, M. (2012). Twenty Years after the Fall: Continuity and Change in Russian Foreign and Security Policy. Global Change, Peace \& Security, 24(2), 203-217. DOI: 10.1080/14781158.2012.679921.

Toal, G. (2017). Near Abroad: Putin, the West, and the Contest over Ukraine and the Caucasus. Oxford: Oxford University Press.

Wasiuta, O. (2017). „Russki mir” jako narzędzie imperialnej polityki Kremla. Przegląd Geopolityczny, 21, 67-87.

Włodkowska-Bagan, A. (2013). Rywalizacja mocarstw na obszarze poradzieckim. Warszawa: Difin.

Włodkowska-Bagan, A. (2017). Polityka Rosji na obszarze poradzieckim. Wschodni Rocznik Humanistyczny, 14(3), 61-87.

Zhiltsov, S. (2018). The Post-Soviet Space: Previous Development and a New Configuration. Central Asia and the Caucasus, 19(3), 7-17. 